\title{
Screen Recorder for Guiding Distance Learning: Case Study of Teacher Professional Education Program
}

\author{
https://doi.org/10.3991/ijet.v16i07.21173 \\ Agung Wiradimadja ${ }^{(凶)}$, Nurul Ratnawati, Bayu Kurniawan \\ Universitas Negeri Malang, Malang, Indonesia \\ agung.wiradimadja.fis@um.ac.id \\ Rahmati Putri Yaniafari \\ Universitas Negeri Malang, Malang, Indonesia \\ Justsinta Sindi Alivi \\ University of Warwick, Coventry, UK
}

\begin{abstract}
The Covid-19 pandemic has negatively impacted societies in many sectors, including education sector. One of the effects is that teaching and learning activities cannot be done in campus, thus Teacher Professional Education or PPG (Pendidikan Profesi Guru) that used to be conducted in campus, should be carried out online by using LMS (Learning Management System) called SIM PKB. The problem is that the students are not familiar with the LMS used, which cause most of them to experience technical problems in the process of the digital learning. This condition requires the class administrators to guide them in using the LMS. This article discusses the use of a screen recorder application to guide PPG students' learning. This research was conducted by observing the digital learning activities of PPG students in SIM PKB LMS before and after watching a video tutorial made using screen recorder application. The results show that the use of screen recorder is effective in helping class administrators to guide the students in operating the LMS. Before the video tutorial was published, there was a virtual meeting with the same objective. However, still, there were so many inquiries about particular functions in the LMS. After the video tutorial was given to the students, there was no more complain regarding technical problems, because the video tutorials can be played repeatedly. Once the video downloaded, the students can play it despite their unstable internet connections. In this case, screen recorders can also save more on the internet quota consumption.
\end{abstract}

Keywords - Screen recorder, distance learning, digital learning, teacher training

\section{Introduction}

The massive spread of Covid-19 in Indonesia in early March 2020 made the Indonesian Minister of Education take the decision to close campuses and limit campus 
activities, especially those inviting large number of people, including lectures. This decision was taken by considering the health and the safety of the academia. It is also act as a preventive action which tries to address the spread of the Covid-19 virus in the campus environment[1], [2]. This decision was immediately responded by most universities by issuing a set of regulations for Online Learning during pandemic. Many lecturers are forced to carry out online learning using provided Learning Management System (LMS)[3]. This technology facilitates learning without limits in real time and place[4], [5], and allows lecturers and students to communicate through the LMS[6], [7].

Teacher Professional Education (PPG) is a program created by the government to improve teachers' professionalism. In this program, the teachers were usually trained for around 5 months in universities. However, due to the pandemic, Lecture activities for the PPG program which were previously carried out online and offline, in 2020, all the activities are conducted online[8]. Advancement in information technology has brought several changes in higher education. It changes and modifies conventional learning methods[9]-[11], but still provides encouragement for participatory learning, and improves students' soft skills[12].

The PPG teaching and Learning process is carried out using the LMS from the Sustainable (and) Professional Development Management Information System (SIM PKB) provided by the government. This PKB SIM LMS was developed from Moodle. Universities in the United States and United Kingdom have already implemented this type of LMS in learning. Browne et al. and Hawkins et al. reported that more than 90\% universities in the United States and in the UK apply LMS in learning[13], [14] as Moodle system supports effective learning through educational content, monitoring and evaluation[15].

There are various models of tasks in PKM SIM LMS, and those tasks need to be completed differently. There are three important roles in the digital learning using this PKM SIM LMS, the first is the lecturer (the facilitator), the second is the campus staff (the administrator of the LMS), and the third is the students. The LMS provides learning materials and both formative and summative test items. Learning activities that must be carried out by students at this LMS are reading the teaching materials, video conferencing synchronously, having discussions with other students and lecturers, and completing formative and summative tests. The user interface of SIM PKB LMS can be seen in figure 1 . 


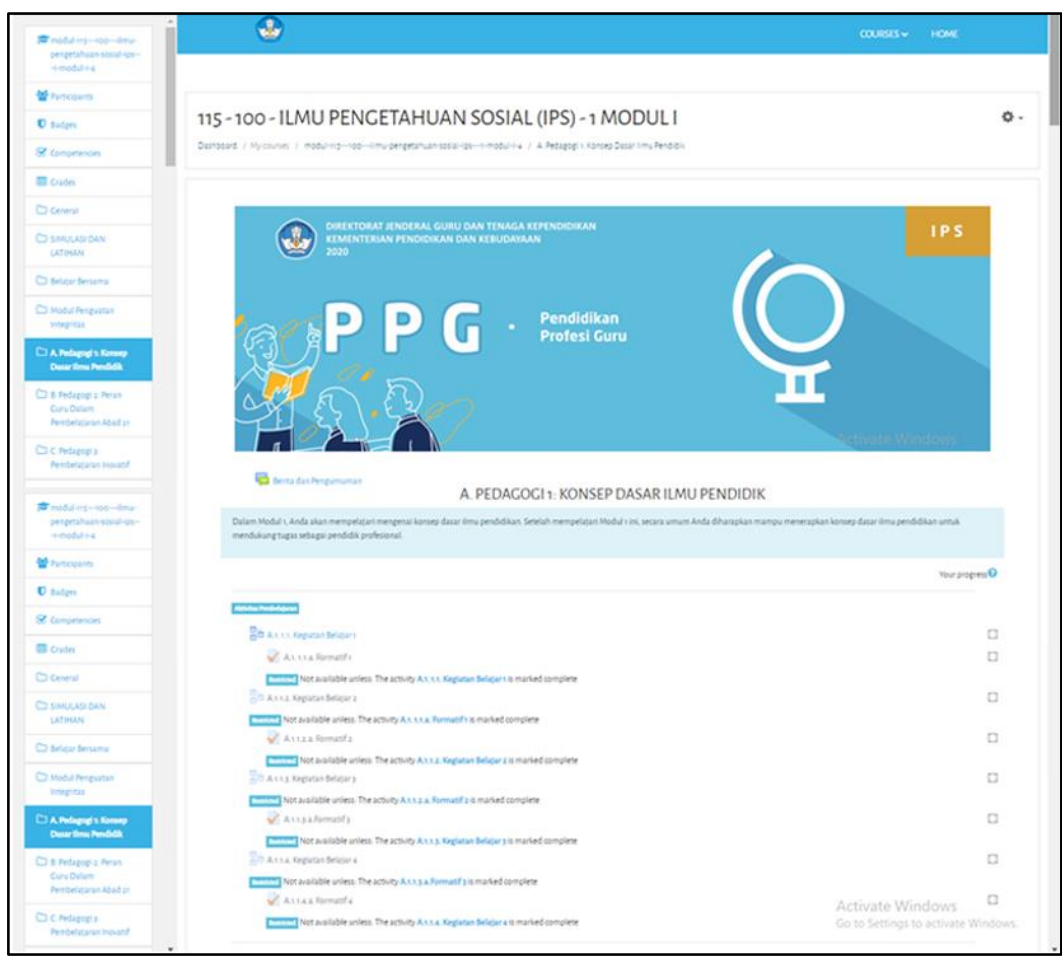

Fig. 1. The user interface of LMS SIM PKB

In practice, digital learning creates problems for the PPG students, who are not digital natives. The problem experienced by students is that they are not familiar with LMS SIM PKB. This causes them to experience technical problems in digital learning, especially in operating the LMS. Then, during the learning activities, they always ask the LMS administrator the detail steps of using the LMS either via text message or telephone. This condition certainly makes it difficult for the LMS administrator to guide the students one by one. Whereas, before the learning activities were carried out, training on the use of LMS via video conference had been held. However, because the steps that students should do in digital learning are quite a lot, they are still confused and unable to operate the LMS. This condition is in line with the survey results from Faculty study 2017 and Purwanto et al. which state that technology integration and mastery of technology in learning are still challenging. Most of the professional teachers have not developed technology-based learning, so students are not used to learn online using LMS[16], [17].

The skill in using technology in learning is an important component for the development of higher education in the coming years. Alexander et al. stated that the skill in the use of technology in learning needs to be optimized[17], [18]. In order to achieve this, the LMS administrators tried to use a screen recorder application to guide the students. 
This article discusses the use of a screen recorder for guiding distance learning using LMS SIM PKB. This study seeks to answer the question: How effective is the use of screen recorder in guiding students in operating LMS SIM PKM? How to guide distance learning when the internet connection is unstable? How much internet quota is used by the students in accessing video tutorial made by screen recorder?

\section{Method}

This research is a descriptive qualitative research using the analysis model of Miles, Huberman and Saldana with the research flow of data condensation, data display, and conclusion drawing/verification[19]. The flow of this research activity is illustrated in Figure 2.

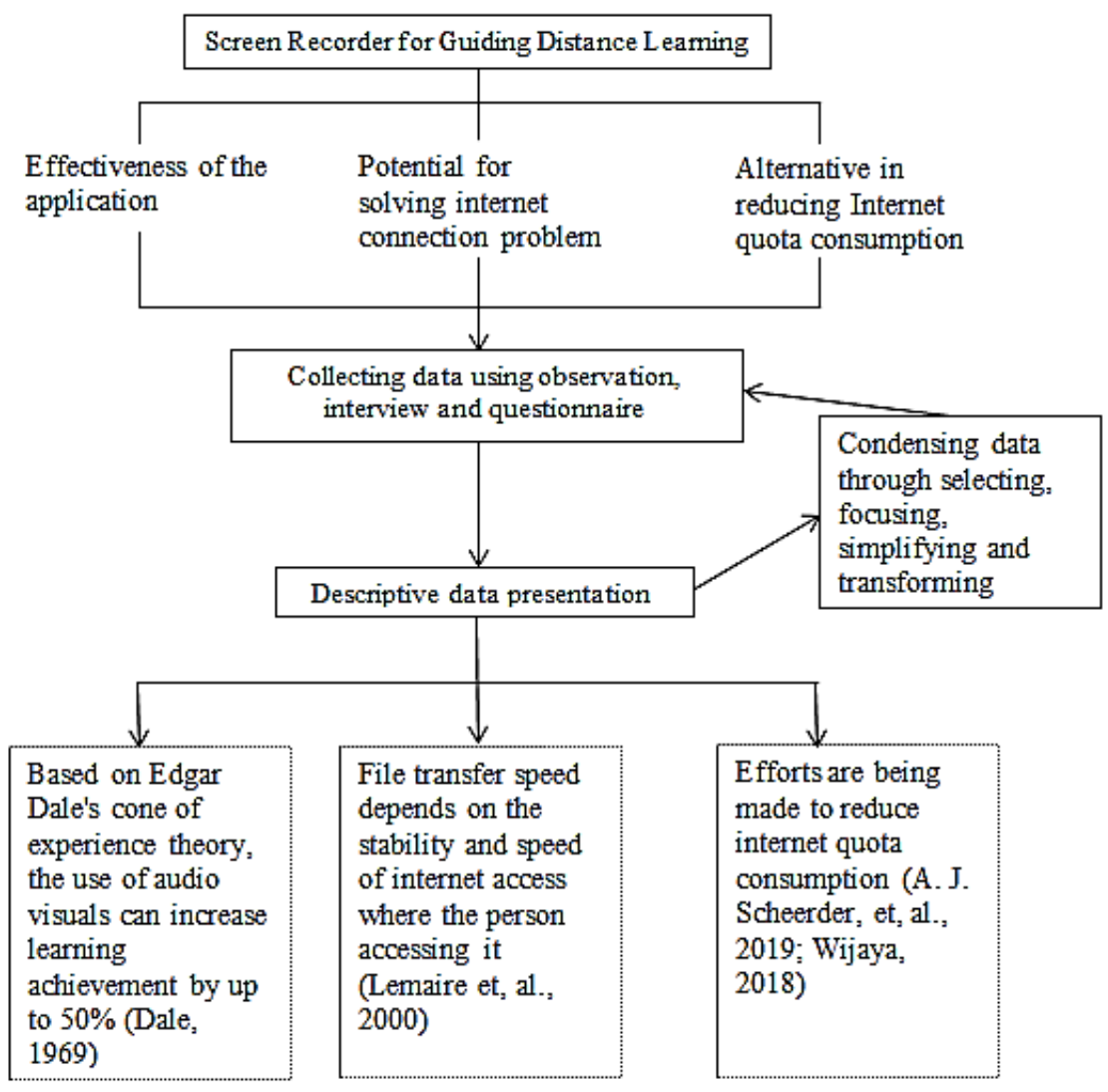

Fig. 2. Data Analysis Technique (adapted from Miles, Huberman and Saldana)[19] 
Data collection in this study was carried out by observing students' communication during learning activities on SIM PKB LMS and also distributing questionnaires using google form to get the data of students' internet data consumption. The number of PPG IPS students involved in this study was 169 people. The students enrolling in this program are from various provinces in Indonesia, such as Riau, North Sumatra, South Sumatra, Jambi, Bengkulu, Lampung, Bangka Belitung, Banten, West Java, East Java, Bali, West Nusa Tenggara, East Nusa Tenggara, West Kalimantan and Central Kalimantan. The percentage of students' distribution can be seen in figure 3 .

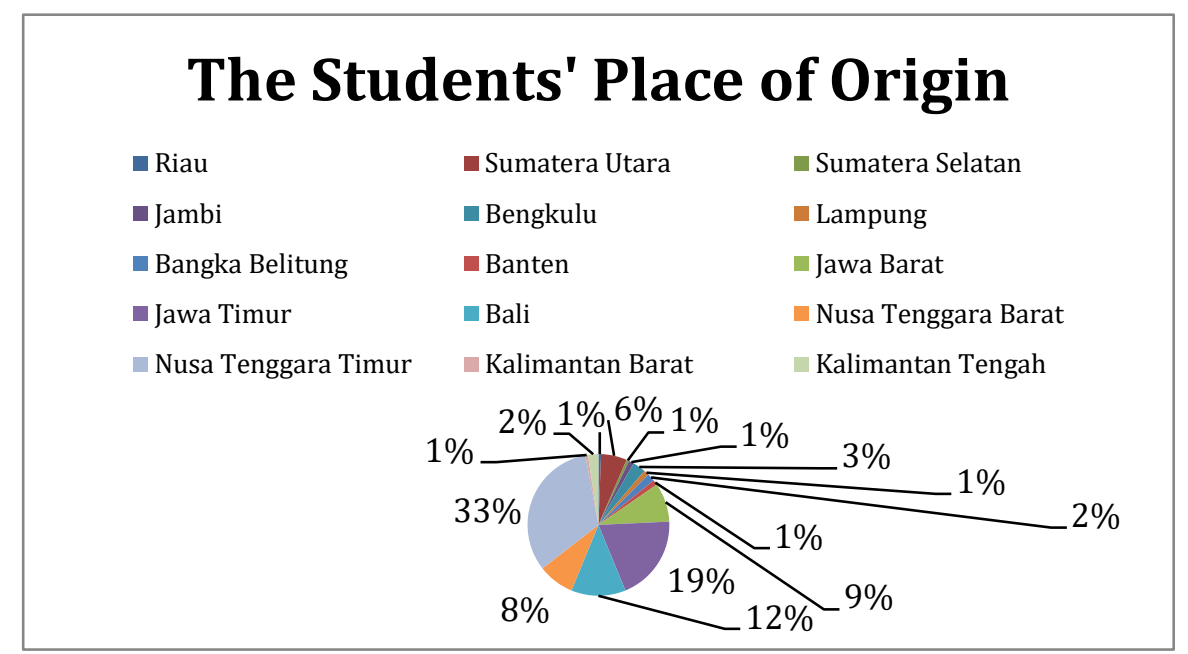

Fig. 3. Percentage of the Students' Place of Origin

The observation was carried out by recording the conversation between students and the LMS administrators in WhatsApp group during the first 30 days of the program. This is to record the students' progress in using the LMS. Each of the students' inquiry regarding the LMS is answered by the LMS administrators by using a video tutorial recorded by using a screen recorder. Students' responses to the LMS administrators' video and questionnaire were analyzed to see the effectiveness of using a screen recorder in guiding students in digital learning.

There are two screen recorder applications used by the LMS administrators in this study, namely Screencast-O-Matic and AZ Screen Recorder. To record all activities on the computer screen, the LMS administrators used Screencast-O-Matic, while to record the smartphone screen, they used the Az Screen Recorder. Both of these applications were also equipped with features to record the voice from the recording maker. The user interfaces of the two applications can be seen in figures 4 and 5 . 


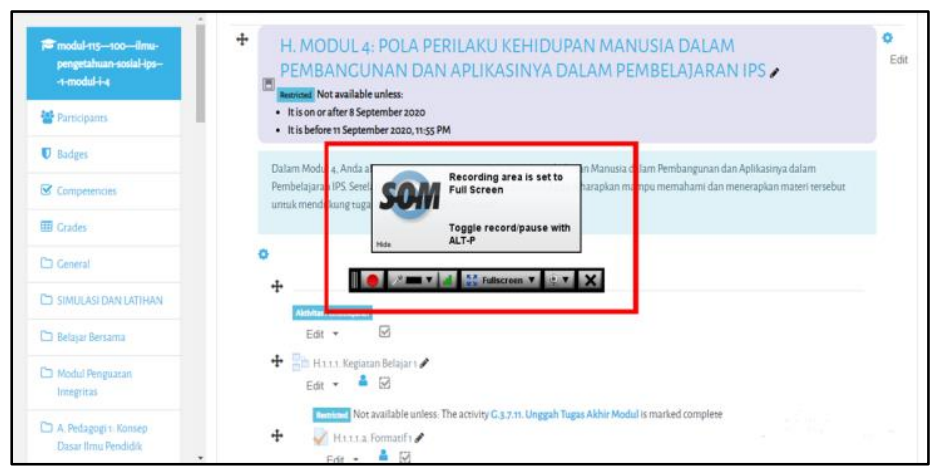

Fig. 4. Application Screencast-O-Matic

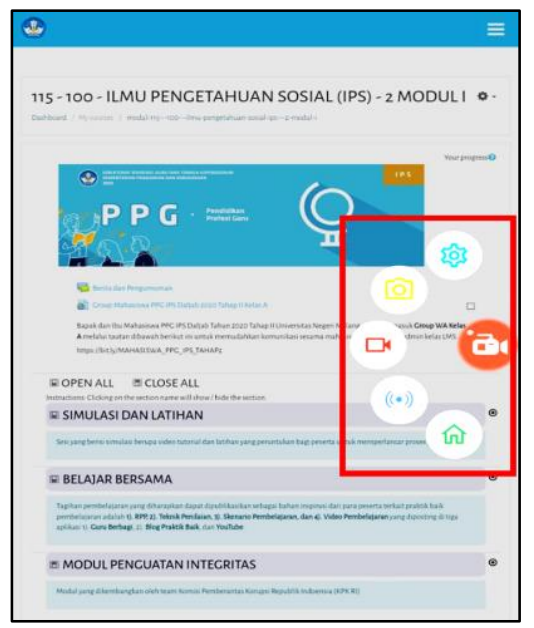

Fig. 5. Application AZ Screen Recorder

\section{$3 \quad$ Result and Discussion}

\subsection{Effectiveness of screen recorders in guiding digital learning}

Prior to implementing digital learning, the students did not get any training in using theLMS from the Directorate General of Teachers and Education Personnel (Dirjen GTK). The majority of students come from areas with poor internet connection. Soemartono and Brata said that internet usage in areas outside Java and Bali is still very low due to limited internet infrastructure such as fiber optics[20]. This adds to the list of reasons underlying the difficulty of students operating the LMS. In fact, this LMS was developed using the Moodle platform which is quite popular in digital learning[21], [22]. 


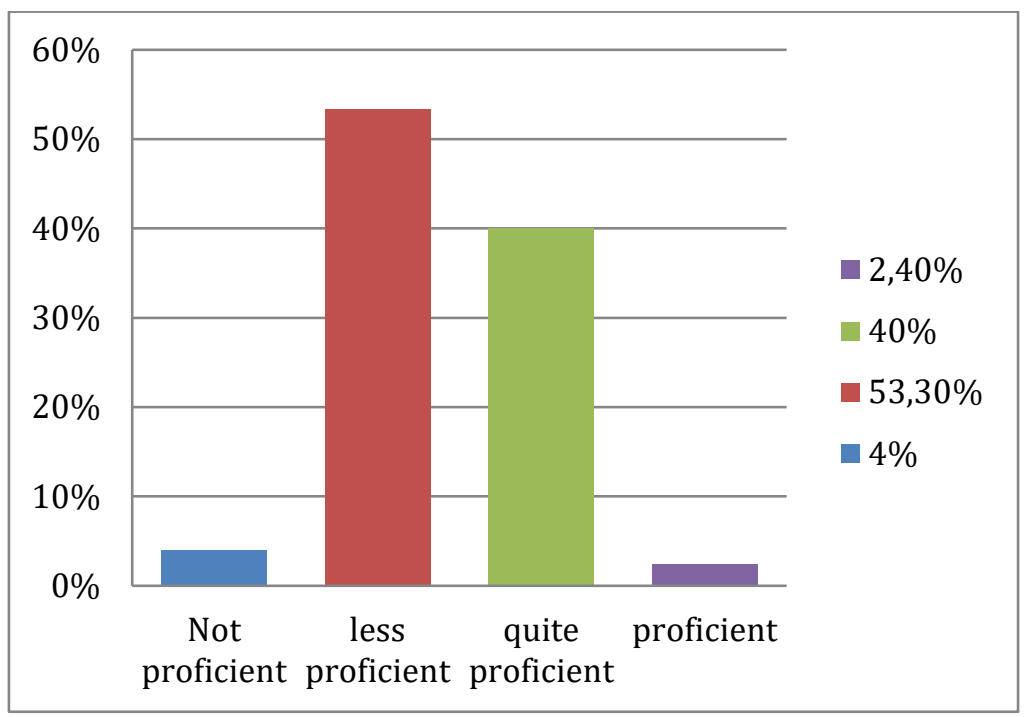

Fig. 6. Mastery level of ICT

Based on the research results, only $2.4 \%$ of the students are proficient ICT users, while those who stated that they are quite proficient are 40\%, 53.3\% are less proficient and $4 \%$ are not proficient (see Figure 6). This means that on average, students' skill to use LMS is considered low.

Considering that skill in using LMS is one of the key success in learning[17], especially in this teacher professional education program, LMS administrators tried to help students by conducting direct training via video conference. However, the results of the training could not effectively overcome the technical obstacles of the students. After joining the training, many students still asked technical questions regarding the use of the LMS. This indicates that online training activities in using the LMS could not solve the problem optimally. The results of this study support Iqbal's statement which states that the difficulty of students in operating the LMS is because the steps that must be taken and remembered are too many and complex, while the duration of the training is quite short[21].

The screen recorder application is used by the LMS Administrators to guide students who experience technical difficulties in operating the LMS. The LMS administrators helped to make a short video tutorial in using the LMS to answer students' inquiry. As a result, the screen recorder could solve these problems. Students could better understand and remember the steps they have to take in operating the LMS. Based on the results of the observations, there was no more inquiries regarding the use of the LMS. Based on the students' accounts, they said that they could play the video many times until they understand the LMS. The results of this study support the statement of Elfeky et al. that LMS video tutorials can make students understand the steps comprehensively. It also helps them identify and follow the main courses of digital learning[23]. Referring to Edgar Dale's cone of experience theory, the use of audiovisuals here includes viewing and listening to demonstrations, which are then followed 
by implementing and practicing activities. This activity can increase learning achievement by up to $50 \%[24]$. This is a considerable achievement in learning activities, the learning activities referred to here are of course learning how to operate the LMS SIM PKB. Bandyopadhyay and Fraccastoro added that the continuous use of this technology can build positive perceptions, thereby eliminating the complicated perceptions in using the technology[25].

\subsection{Screen recorder and the internet connection problem}

As previously stated, the internet connection outside Java and Bali is still not good enough[20]. In some areas, it is unstable; It often weakens during certain times such as rainy season. Based on the results of the study, around $41.4 \%$ of students did not install in-home-Wifi because there was no LAN internet network facility. Even if there is an internet network, the connection is always interrupted. This, of course, a big challenge for digital/online learning. Unlike the case in Utah, United States. Barbara et al. stated that the cause of digital learning problems in Utah was the lack of qualified candidates as teachers[26], whereas in this study the problem was the availability and the quality of internet connection.

The process of synchoronous distance learning is largely determined by the quality, speed and stability of internet access. The students said that during the LMS training activities which were carried out synchronously through video conferencing, the internet connection was often interrupted so that sound and video were intermittent. This then make some of the information not clearly conveyed to the students. This condition supports the statement of Barbara et al. stating that to carry out synchronous learning through video conference, all the participants must have a stable internet connection[26].

The students said that they could only wait for a stable internet connection for a few minutes or even hours. Some of them have to go 30-80 kilo meters away from home every day just to get a stable internet connection. This is a different effort compare to what Hamdan had dome. He improved the internet connection by making simple devices from used soft drink cans[27].

The videos produced by both screen recorder applications are MPEG4 (mp4) with a resolution of 1366x768 pixels and 10 frames / s for Screencast-O-Matic, while for the $\mathrm{Az}$ Screen recorder, it is $1440 \times 720$ pixel 5 frames / s. Based on the research results, the researcher found that this problem could be solved using a screen recorder application. Unlike video conference which always rely on the quality, speed and stability of internet access, screen recorders are not constrained by those factors. Screen recorders don't always have to rely on strong internet connection. However, when the stability of the internet decreases the video sending process is a bit slower, which is far less challenging compare to video conference. This is in line with the research of Lemaire et al. that the file transfer speed in the form of an image or video depends on the stability and speed of internet access in the place where the person is accessing it. If the connectivity is strong and stable, data transmission can be sent faster, but if the connection is weak ad unstable, the data transfer can take longer[28]. When the internet connection is stable, students can download videos sent by the LMS administrators 
within minutes. The video tutorials that had been downloaded were stored in the students' gadget drive so that they could open the video repeatedly anytime.

\subsection{Alternative in reducing internet quota consumption}

In digital learning era, especially for synchronous online learning, internet quota consumption is still one of the obstacles in Indonesia; because learning using video conferencing can consume more internet quota[29], [30] while the price of internet quota in Indonesia is still considered quite expensive[31]. Internet quota consumption for one hour of LMS training using video conference could spend up to $308 \mathrm{Mbps}$ using the Zoom application and 483.5 Mbps when using the Google Meet application. The finding shows that students mostly use internet quotas from smartphones for learning purposes so they have to save on internet consumption.

Based on a survey, the internet quota budget for 46 students $(27,2 \%)$ per month is not more than $15 \mathrm{~Gb}$. However, if the LMS training and guidance were provided purely by using video conference, the quota spent could be way more than that. Seeing the condition of the students that put a lot of effort to minimize the amount of internet quota consumption, the administrators also tried not to burden them through the use of screen recorder application. The duration of the video tutorials provided by the LMS administrators were of 1-15 minutes. Based on the observations, the internet quota capacity for sending video files is only $1.7 \mathrm{Mb}$ to $39.5 \mathrm{Mb}$. Of course, this can greatly save students' internet quota compared to providing guidance on using LMS using video conference. As many as 38 students decided to use the wifi facilities provided by the government, the school where they teach, wifi in public places and even turn off the camera during a video conference to save their internet quota. This is different from findings of studies conducted by A.J. Scheerder, et,al. which observes the internet use of families of Low Education Attainment (LEA) and Higher Education Attainment (HEA) group in the Netherlands. To save their internet quota, the LEA groups do not use public wifi facilities, but they tried to limit their children's use of the internet or even they stopped using social media[32]. It is also different from what Wijaya has done in terms of saving and efficiently consume internet quota, which is by applying Asynchronous JavaScript And XML (AJAX)[31].

\section{Conclusion}

The problem that occurs in the PPG distance learning program is that the students are not skillful in operating the LMS. This hindered the process of their learning activities. To deal with this problem, the LMS administrators tried to guide the students by using a video screen recorder. The results showed that the video screen recorder effectively guides students in operating the LMS used in the distance learning. Students could comprehensively understand every step they have to take. This video screen recorder can also solve the problem of an unstable internet connection at times. The videos they have downloaded are stored on their gadgets' drive so they can be played many times without having to ask the LMS administrators again. Using this video 
screen recorder can also save the internet quota compare to providing training synchronously using video conference.

\section{$5 \quad$ References}

[1] N. A. Makarim, "Surat EdaranPencegahan COVID-19 pada Satuan Pendidikan," Kementerian Pendidikan dan Kebudayaan, 2020. https://www.kemdikbud.go.id/main/blog/ 2020/03/surat-edaran-pencegahan-covid19-pada-satuan-pendidikan (accessed Aug. 24, 2020). https://doi.org/10.24832/jpnk.v19i4.304

[2] A. Na'im, "Surat EdaranSekretarisJenderal Kementerian Pendidikan dan Kebudayaan RI No.35492/A.A5/HK/2020 tanggal 12 Maret 2020 tentangPencegahan Corona Virus Disease-19," Kementerian Pendidikan Dan Kebudayaan, p. 1, 2020. https://doi.org/10.36310/jebi.v13i2.98

[3] A. Hutchison, "Technological Efficiency in The Learning Management System: A Wicked Problem with Sustainability for Online Writing Instruction," Computers and Composition, vol. 54, p. 102510, Dec. 2019. https://doi.org/10.1016/j.compcom.2019.102510

[4] N. Ain, K. Kaur, and M. Waheed, "The influence of learning value on learning management system use: An extension of UTAUT2,” Information Development, vol. 32, no. 5, pp. 13061321, Nov. 2016. https://doi.org/10.1177/0266666915597546

[5] N. Cavus and A. M. Momani, "Computer aided evaluation of learning management systems," Procedia - Social and Behavioral Sciences, vol. 1, no. 1, pp. 426-430, 2009. https://doi.org/10.1016/j.sbspro.2009.01.076

[6] K. Al-Busaidi and H. Al-Shihi, "Instructors' Acceptance of Learning Management Systems: A Theoretical Framework," Communications of the IBIMA, pp. 1-10, Jan. 2010. https://doi.org/10.5171/2010.862128

[7] S. Lonn, S. D. Teasley, and A. E. Krumm, "Who needs to do what where? Using learning management systems on residential vs. commuter campuses," Computers \& Education, vol. 56, no. 3, pp. 642-649, Apr. 2011. https://doi.org/10.1016/j.compedu.2010.10.006

[8] Kemendikbud, "InformasiPelaksanaan PPG DaljabTahun 2020," 2020. https://ppg.kemdikbud.go.id/pelaksanaan-ppg-daljab-tahun-2020/ (accessed Aug. 24, 2020).

[9] A. Hassanzadeh, F. Kanaani, and S. Elahi, "A model for measuring e-learning systems success in universities," Expert Systems with Applications, vol. 39, no. 12, pp. 10959-10966, Sep. 2012. https://doi.org/10.1016/j.eswa.2012.03.028

[10] M. K. Asamoah, "ICT officials' opinion on deploying Open-Source Learning Management System for teaching and learning in universities in a developing society," E-Learning and Digital Media, p. 2042753020946280, Aug. 2020. https://doi.org/10.1177/204275302 $\underline{0946280}$

[11] N. Mukminatien, R. P. Yaniafari, T. Kurniawan, and A. Wiradimadja, "CLIL Audio Materials: A Speaking Model for Library Science Department Students," International Journal of Emerging Technologies in Learning (iJET), vol. 15, no. 07, Art. no. 07, Apr. 2020. https://doi.org/10.3991/ijet.v15i07.13223

[12] B. Kurniawan, I. Idris, A. Purnomo, A. Wiradimadja, and S. Sukamto, "Using Broadcasting Learning Design to Enhance Student's Experiential Skill," International Journal of Emerging Technologies in Learning (iJET), vol. 14, no. 16, Art. no. 16, Aug. 2019. https://doi.org/10.3991/ijet.v14i16.10652

[13] T. Browne, M. Jenkins, and R. Walker, "A longitudinal perspective regarding the use of VLEs by higher education institutions in the United Kingdom," Interactive Learning Envi- 
ronments, vol. 14, no. 2, pp. 177-192, Aug. 2006. https://doi.org/10.1080/10494820 $\underline{600852795}$

[14] B. L. Hawkins and J. A. Rudy, EDUCAUSE Core Data Service: Fiscal Year 2007 Summary Report. EDUCAUSE, 2008.

[15] M. Zabolotniaia, Z. Cheng, E. Dorozhkin, and A. Lyzhin, "Use of the LMS Moodle for an Effective Implementation of an Innovative Policy in Higher Educational Institutions," International Journal of Emerging Technologies in Learning (iJET), vol. 15, no. 13, Art. no. 13, Jul. 2020. https://doi.org/10.3991/ijet.v15i13.14945

[16] A. Purwanto et al., "StudiEksploratifDampakPandemi COVID-19 Terhadap Proses Pembelajaran Online di Sekolah Dasar," EduPsyCouns: Journal of Education, Psychology and Counseling, vol. 2, no. 1, Art. no. 1, Apr. 2020.

[17] B. Alexander et al., Educause Horizon report: 2019 Higher Education edition. 2019.

[18] A. H. Duin and J. Tham, "The Current State of Analytics: Implications for Learning Management System (LMS) Use in Writing Pedagogy," Computers and Composition, vol. 55, p. 102544, Mar. 2020. https://doi.org/10.1016/j.compcom.2020.102544

[19] M. B. Miles, A. M. Huberman, and J. Saldaña, Qualitative data analysis: a methods sourcebook, Fourth edition. Los Angeles: SAGE, 2020.

[20] H. K. Soemartono and T. Brata, "Potret zaman now penggunan\&perilaku internet Indonsesia," AsosiasiPenyelenggara Jasa Internet Indonesia (APJII), vol. April, no. 23, 2018

[21] S. Iqbal, "Learning Management Systems (LMS): Inside Matters," Social Science Research Network, Rochester, NY, SSRN Scholarly Paper ID 3331024, Oct. 2011. Accessed: Sep. 02, 2020. [Online]. Available: https://papers.ssrn.com/abstract=3331024

[22] M. Waheed, K. Kaur, and A. Qazi, "Students' perspective on knowledge quality in eLearning context: a qualitative assessment," Internet Research, vol. 26, no. 1, pp. 120-145, Jan. 2016. https://doi.org/10.1108/intr-08-2014-0199

[23] A. I. M. Elfeky, T. S. Y. Masadeh, and M. Y. H. Elbyaly, "Advance organizers in flipped classroom via e-learning management system and the promotion of integrated science process skills," Thinking Skills and Creativity, vol. 35, p. 100622, Mar. 2020. https://doi.org/10.1016/j.tsc.2019.100622

[24] E. Dale, Audiovisual methods in teaching. New York a.o: Dryden Press, 1969.

[25] K. Bandyopadhyay and K. A. Fraccastoro, "The Effect of Culture on User Acceptance of Information Technology," CAIS, vol. 19, 2007. https://doi.org/10.17705/1cais.01923

[26] B. J. Fiechtl and K. D. Hager, "A Statewide Early Childhood Alternative Teacher Preparation Program Delivered via Synchronous Video Conference," Rural Special Education Quarterly, vol. 38, no. 4, pp. 210-216, Dec. 2019. https://doi.org/10.1177/875687 $\underline{0519860069}$

[27] H. An and S. Supriyanto, "PENGUATAN PENERIMAAN SINYAL MENGGUNAKAN BAHAN KALENG BEKAS MINUMAN PADA JARINGAN WIRELESS INTERNET," Teknika: JurnalSains dan Teknologi, vol. 7, no. 1, Art. no. 1, Jun. 2011. https://doi.org/10.36055/tjst.v8i1.6702

[28] E. D. Lemaire, Y. Boudrias, and G. Greene, "Technical evaluation of a low-bandwidth, Internet-based system for teleconsultations," J Telemed Telecare, vol. 6, no. 3, pp. 163-167, Jun. 2000. https://doi.org/10.1258/1357633001935266

[29] N. I. Pratiwi, "Penggunaan Media Video Call Dalam Teknologi Komunikasi," JurnalIlmiahDinamikaSosial, vol. 1, no. 2, Art. no. 2, Aug. 2017, doi: 10.38043/jids.v1i2.219.

[30] A. H. Rustaman, "EfektivitasPenggunaanAplikasi Daring, Video Conference Dan Sosial Media Pada Mata KuliahKomputerGrafis 1 Di Masa Pandemi Covid-19," JISIP (JurnalIlmuSosial dan Pendidikan), vol. 4, no. 3, Art. no. 3, Jul. 2020, doi: 10.36312/jisip.v4i3.1274. https://doi.org/10.36312/jisip.v4i3.1155 
[31] T. Wijaya, "Penerapan AJAX dalamAplikasi Mobile Berbasis Web UntukMeningkatkanEfisiensi Bandwidth," Techno.Com, vol. 17, no. 2, Art. no. 2, May 2018. https://doi.org/10.33633/tc.v17i2.1687

[32] A. J. Scheerder, A. J. van Deursen, and J. A. van Dijk, "Internet use in the home: Digital inequality from a domestication perspective," New Media \& Society, vol. 21, no. 10, pp. 2099-2118, Oct. 2019. https://doi.org/10.1177/1461444819844299

\section{Authors}

Agung Wiradimadja is one of the lecturers in Social Studies Program, Faculty of Social Science, Universitas Negeri Malang. He is interested in social studies education, social studies curriculum, learning innovation, and learning media. Email: agung.wiradimadja.fis@um.ac.id

Rahmati Putri Yaniafari is an academic staff of the Department of English, Faculty of Letters, Universitas Negeri Malang. She has a keen interest in English Language Teaching, especially Autonomous Learning, Computer Assisted Language Learning (CALL), and CLIL (Content and Language Integrated Learning). Email: yaniafari.fs@um.ac.id

Nurul Ratnawati is a lecturer in Faculty of Social Science, Universitas Negeri Malang, Indonesia. Her research interests are curriculum development and learning media. Email: nurul.ratnawati.fis@um.ac.id

Bayu Kurniawan is an Indonesian Historical Education, one of the lecturers in Faculty of Social Science, Universitas Negeri Malang. His research interest is education, learning innovation and learning media. Email: bayu.kurniawan.fis@um.ac.id

Justsinta Sindi Alivi is $\mathrm{PhD}$ candidate at the University of Warwick, The United Kingdom. She has a great interest in a topic concerning the use of Information and Communication Technology (ICT) in teaching practice, particularly in the teachers' uptake of ICT use. Her research has been discussing and reviewing TPCAK Teaching, Pedagogical, and Content Knowledge (TPACK). Email: s.alivi@warwick.ac.uk

Article submitted 2021-01-04. Resubmitted 2021-02-25. Final acceptance 2021-02-28. Final version published as submitted by the authors. 